\title{
Has research and development contributed to improvements in safety and profitability of deep South African mines?
}

\author{
RJ Durrheim University of the Witwatersrand and CSIR, South Africa
}

\begin{abstract}
The remarkably rich and persistent gold and platinum deposits in South Africa stimulated the development of a deep mining industry. The challenges of mining laterally-extensive orebodies at depths as great as $4 \mathrm{~km}$ include high rock stress and temperature, and large vertical and horizontal distances over which personnel, materials and rock must be transported. Innovation was driven by entrepreneurial zeal, private-public partnerships, government regulation, and labour activism. Despite the development and widespread implementation of many technologies critical to successful deep mining, there has been a major decline in domestic research and development (R\&D) activity and capacity during the past two decades. Nevertheless, there are some areas of research where South African researchers continue to break new ground, notably the application of reflection seismology in the hard rock environment, studies of rockburst mechanisms, and the development of systems to monitor the underground environment. Changes in the social, economic and political landscape since the advent of democracy in South Africa in 1994 have also had a major impact on the deep mining industry, and will most likely accelerate efforts to increase the level of mechanisation and automation.
\end{abstract}

\section{Introduction}

To thrive and have a social licence to operate, mines should have safe and healthy working conditions, pay decent wages, have a limited impact on the environment, and, of course, be profitable. Mining has been the cornerstone of South Africa's economy, and currently contributes about $10 \%$ of GDP. However, mining has also exacted a considerable human toll; more than 75,000 lives have been lost in mining accidents since 1900 (Department of Mineral Resources 2012). In addition, the flooding of worked-out gold mines has made it necessary to treat acidic groundwater at considerable cost to the taxpayer (Creamer 2014b).

Mining-related research was conducted in an ad hoc fashion in South Africa until 1960, when a large collapse at the Coalbrook colliery, near the town of Parys in the Free State province, claimed 435 lives. This disaster led to the establishment of the Chamber of Mines Research Organisation in 1964. Since then, there have been major improvements in mining safety, especially during the past two decades, although South Africa still lags behind many international benchmarks. Many attempts have been made to mechanise the rock-breaking process in gold and platinum mines, both to reduce the exposure of mine workers to risk and to improve efficiencies, but with limited success so far.

This paper briefly reviews the history of innovation in the South African deep mining industry, discusses current initiatives, and seeks to assess the contribution made by R\&D and to forecast future trends.

\section{Deep mining in South Africa}

Gold was discovered in quartz pebble conglomerates that crop out in present-day Johannesburg in 1886 (Viljoen \& Reimold 1999). Since then, the Witwatersrand Basin has produced almost one third of the gold ever mined (Handley 2004), and arguably still contains over half of the world's identified remaining gold resources. The conglomerates were deposited in an Archaean sedimentary basin, and were subsequently covered by younger strata. Magnetic and gravity surveys were used to trace the orebodies (locally known as reefs) beneath the cover rocks, and new gold fields were discovered in the East Rand in 1914, the Far 
West Rand and Klerksdorp districts in 1937, the Free State province in 1946, and the Kinross district in 1955. The reefs persist to great depths, bringing about many challenges; notably increases in rock stress and temperature, and the distances over which personnel, materials and rock must be transported.

Deep gold mining poses many safety and health risks to mine workers, including falls of ground and heat stroke. Mining-induced seismicity and its hazardous manifestation, rockbursts, were first encountered in the early 1900s when extensive stopes, supported solely by small reef pillars, reached depths of several hundred metres. These problems required innovative solutions, the success of which has enabled mining today to take place almost $4 \mathrm{~km}$ below the surface. At its peak in 1970, the industry produced 1,000 metric $t$ of gold. The drill-and-blast mining method is labour intensive, and employment peaked at some 500,000 persons in the 1980s. In 2012, gold output and employment declined to $167 \mathrm{t}$ (the lowest level since 1905) and 142,000 miners, respectively. Despite this, gold exports earned ZAR 72 b, surpassing platinum and coal (Creamer 2013).

South Africa is also home to the Bushveld Complex, a huge layered intrusion that contains the world's largest resource of platinum group elements (PGEs). The laterally continuous PGE reefs, discovered in 1924 (Viljoen \& Reimold 1999), persist to depths of several kilometres. Technology, knowledge and experience gained in Witwatersrand gold mines have been adapted and applied to mine the PGE reefs and mitigate the risks posed by high temperatures and stresses. The thermal gradient is considerably higher in the Bushveld Complex because the mafic rocks of the layered portion of the complex, such as pyroxenites, gabbros, norites and anorthosites, have lower thermal conductivities than quartzite. Thus cooling became an issue at comparatively shallow depths. On the other hand, Bushveld rocks are mechanically weaker and less brittle than quartzite, and seismicity only became a source of concern in the 1990s when mining depths approached $1 \mathrm{~km}$.

\section{$3 \quad$ Brief history of research endeavours}

\subsection{State interventions}

As the South African gold mining industry expanded, the State appointed various committees to investigate the origins of the earth tremors and to recommend mitigating measures. In 1908, minor damage in a village near Johannesburg led to the appointment of a committee, chaired by the Government Mining Engineer, to "inquire into and report on the origin and effect of the earth tremors experienced in the village of Ophirton". The Ophirton Earth Tremors Committee found that, "under the great weight of the superincumbent mass of rock ... the pillars are severely strained; that ultimately they partly give way suddenly, and that this relief of strain produces a vibration in the rock which is transmitted to the surface in the form of a more or less severe tremor or shock", and recommended that the support pillars should be replaced by waste packs, and that seismographs should be installed (Anon. 1916). In response to a recommendation of the committee, two $200 \mathrm{~kg}$ Wiechert seismographs were installed in 1910; one at the Union Observatory in Johannesburg and the other in the village of Ophirton. Further committees were convened in 1915 (Anon. 1916) and 1924 (Anon. 1925). The 1915 committee concluded that, "the shocks have their origin in mining operations" (Anon. 1916). The report of the 1924 committee made many recommendations concerning general mining policy, the protection of travelling ways, and the stoping out of remnants (Anon. 1925).

After a hiatus of 40 years, a new committee was mandated to, "study the question of rockbursts and to revise the recommendations of the Witwatersrand Rock Burst Committee (1924)", (Anon. 1964). It was considered opportune to conduct a new investigation as, "not only had mining depths in excess of 11,000 feet below surface been reached on the Witwatersrand, but the rockburst danger had also revealed itself in the newer mining areas of the Far West Rand, Klerksdorp and the Orange Free State". The recommendations of the 1964 committee were based on a considerable body of research and practical observations. The necessity for carrying out further research was noted, and it was, indeed, in 1964 that the Chamber of Mines Research Organisation was founded. 
The Leon Commission of Inquiry into Safety and Health in the Mining Industry was appointed in 1994, shortly after the first democratic elections. It reported that over 69,000 mine workers had died in the first 93 years of this century, and more than a million were seriously injured. The Mine Health and Safety Act of 1996 was drafted, based on the recommendation of the Commission. It contains legislation governing the operation of the Mine Health and Safety Council (MHSC) and the Safety in Mines Research Advisory Committee (SIMRAC).

The largest mining-related seismic event ever recorded in South Africa occurred on 9 March 2005 in the Klerksdorp district about $150 \mathrm{~km}$ southwest of Joahnnesburg. The ML5.3 main shock and aftershocks shook the nearby town of Stilfontein, and caused serious damage to several buildings and minor injuries to 58 people (Figure 1). The No. 5 Shaft at DRDGold's Northwest Operations suffered severe damage. Two mine workers lost their lives, and 3,200 mine workers were evacuated under difficult circumstances.
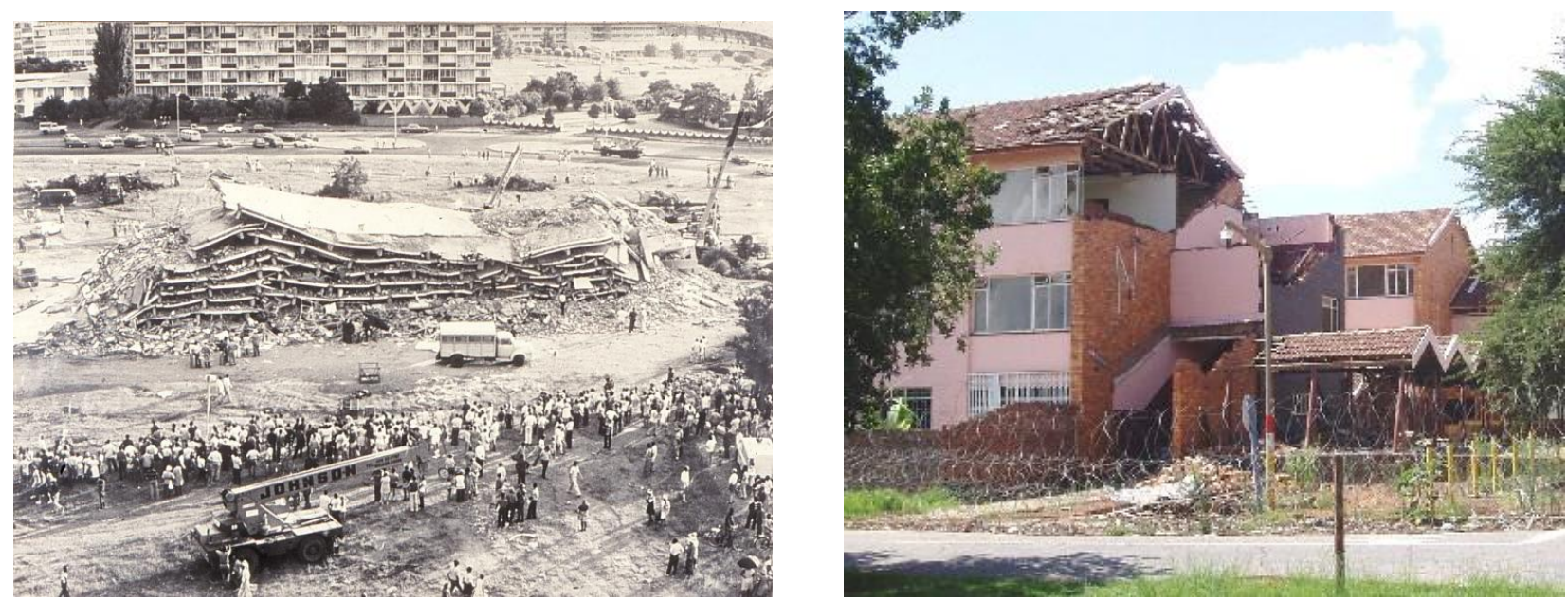

\section{Figure 1 Damage to surface structures caused by large mining-related tremors; (a) Welkom, Free State province, 8 December 1976, ML5.2 and; (b) Stilfontein, Northwest province, 9 March 2005, ML5.3}

This seismic event prompted the Chief Inspector of Mines to appoint an expert panel to investigate some wider concerns regarding the risks posed by gold mining, including:

1. Does mining, past and present, trigger or induce large seismic events and will it continue to do so in the future?

2. Are the technologies available to manage seismicity adequate in the current situation of remnant mining, deeper mines, and mining within large mined-out areas?

3. Are current approaches to planning, design, monitoring, and management appropriate and adequate?

The issues addressed by the 2005 panel were similar to those addressed by earlier committees. However, much had changed since 1964. On the one hand, new technologies had been introduced to address the risks posed by increasing rock stress and temperature. On the other hand, South Africa's gold production had peaked in the 1970s, and new problems had arisen as mines approached the end of their lives, ceased operation, and were allowed to flood. Many of the cities and towns in the gold mining districts had grown, and several seismic events with $M_{L}>5$ had caused damage to residential, commercial, and civic buildings (Figure 1).

The expert panel (Durrheim et al. 2006) concluded that the 9 March 2005 seismic event was the result of extensive mining that had taken place over several decades. Seismic events will continue to occur in the gold mining districts as long as deep-level mining takes place, and are likely to persist for some time after mine closure, especially while they flood. Although regional and in-mine monitoring networks were found to be on a par with those installed in seismically-active mining districts elsewhere in the world, measures to 
improve the quality and continuity of seismic monitoring were recommended, particularly when mines change ownership. The expert panel identified that a range of technologies to mitigate the risks of large seismic events is available. Nevertheless, it was noted that particular care should be taken when mining close to geological features that could host large seismic events.

\subsection{Research organisations}

\subsubsection{Chamber of Mines Research Organisation}

The Witwatersrand Chamber of Mines was formed in 1889, only three years after the discovery of gold. It changed its name several times as the mining industry expanded and political structures evolved, becoming the Chamber of Mines of South Africa in 1967. The Coalbrook Colliery disaster occurred in January 1960. The official enquiry found that there was no scientific basis for the design of pillars in coal mines, and highlighted the need for systematic research. Consequently the Chamber of Mines Research Organisation (COMRO) was established in 1964 to address issues such as coal pillar design and deep mining. In 1986 COMRO employed nearly 700 people. A special issue of Mining Survey to commemorate the centenary of the Chamber of Mines in 1989 identified the following research focus areas related to deep mining:

1. Rock engineering - development of mine layouts that minimised the effect of rock pressure at the design stage; support systems that reduced falls of ground and the extent of rockburst damage; and rockburst control, through the development of instruments to monitor seismicity and engineering techniques to mitigate the rockburst risk.

2. Underground environment - heat load reduction; improved means of cooling and ventilating; protection of personnel against environmental stress; and the handling of hazardous materials.

3. Stoping technology - improvement of current drilling, blasting and rock handling; the development of non-explosive rock-breaking systems; the implementation of backfill, and equipment powered by high-pressure water.

4. Gold exploitation - tools to measure gold grades; predict gold distribution ahead of mining; and to delineate geological structures ahead of mining.

COMRO was downsized in the early 1990s and merged with the Council for Scientific and Industrial Research (CSIR) in 1993.

\subsubsection{CSIR}

CSIR was founded in 1945 and rock mechanics research was carried out in the National Mechanical Engineering Institute (NMERI). CSIR Division of Mining Technology (Miningtek), with a staff complement of about 250, was formed after the merger with COMRO in 1993. CSIR Miningtek carried out a considerable amount of work for SIMRAC and managed the DeepMine and FutureMine collaborative research programmes. Support for mining research, however, declined. The CSIR Centre for Mining Innovation (CMI) was constituted in 2009, with a research staff complement of about 40. The CMI was disaggregated in 2014 and the staff members redeployed to other research units. Mining-related research at CSIR is now led by the Natural Resources and the Environment Unit.

\subsubsection{University of the Witwatersrand}

University of the Witwatersrand, founded in 1922, has its origins in the South African School of Mines, which was established in Kimberley in the Northern Cape province in 1896, and transferred to Johannesburg as the Transvaal Technical Institute in 1904. The Bernard Price Institute for Geophysical Research (BPI) was founded in 1936 and played a leading role in establishing the discipline of mine seismology. The BPI closed in 2003. Mining-related research continues to be carried out in virtually every faculty of the university, and in 2012 the Wits Mining Research Institute was launched. 


\subsubsection{Private sector initiatives}

The challenges of deep mining have also driven research initiatives by mining companies, equipment manufacturers and consultancies. For example, ISS International (ISSI), a company specialising in technologies to monitor and model the rock mass response to mining, was founded in 1990. It has become a world leader in mine seismology technology. In 2010, the Institute for Mine Seismology (IMS) bought the businesses and assets of ISSI. By 2013 ISSI/IMS had installed more than 200 systems worldwide.

\subsubsection{Safety in Mines Research Advisory Committee of the Mine Health and Safety Council}

SIMRAC was established in terms of the Minerals Act (Act 50 of 1991) with the principal objective of advising the MHSC on the determination of the safety risk on mines and the need for research. SIMRAC has the responsibility to identify and provide guidance to research projects, which are administered by the MHSC. Research funding is sourced from a levy imposed on all the operating mines in South Africa. The MHSC also negotiates agreements for carrying out such projects with research organisations, monitors project progress, and communicates the results of research to all parties concerned. SIMRAC identified rockbursts and rockfalls as serious safety hazards, particularly in gold mines. From 1991 to 2004, the MHSC, under the guidance of SIMRAC, spent more than ZAR $250 \mathrm{~m}$ on rock-related research, representing some 500 man-years of effort. For comprehensive reviews, see Adams \& Van der Heever (2001) and Durrheim et al. (2005).

A study was commissioned in 2004 to assess the scope, quality and impact of South African rock-related research in general, and the SIMRAC research programme in particular (Durrheim et al. 2005). It was concluded that SIMRAC had succeeded in identifying the major research needs and had coordinated a comprehensive programme of research. In particular, it was found that SIMRAC-supported research had contributed to the development of several important new technologies, such as systems for seismic monitoring and analysis, dip-pillar mining layouts, pre-conditioning and pre-stressed elongates. Furthermore, SIMRAC-supported research had also contributed to the work of the collaborative research programmes and the formulation of the mandatory "codes of practice to combat rockfall and rockburst accidents". The relatively small impact of the research effort on safety statistics was attributed to the increasing depth of mining, the increasing proportion of remnant and pillar mining, the failure to achieve short term prediction, the long lead-time for new knowledge to be implemented, and shortcomings in the knowledge and technology transfer process.

\subsubsection{Collaborative research programmes}

DeepMine (1998-2002) sought to create the technological and human resources platform to mine gold safely and profitably at depths of 3-5 km (Durrheim 2007). The five year ZAR $66 \mathrm{~m}$ programme of research was sponsored by AngloGold, Durban Roodepoort Deep, Gold Fields, the Chamber of Mines of South Africa, CSIR, and the Department of Trade and Industry. The scope of work included occupational health and safety; the delineation of geological structures ahead of mining; mining layouts and sequences; stope support; seismic management; refrigeration and ventilation; access development and support; transport of men, material and rock; energy systems; and orebody evaluation.

The DeepMine process followed the following stages:

1. Define the ultra-deep environment (e.g. rock types, stress, temperature).

2. Establish systems criteria (e.g. maximum energy release rate, maximum temperature in working places, desired face advance rate).

3. Assess if currently available technologies meet the systems criteria.

4. Conduct research to fill the knowledge or technology gaps.

In its first year (1998/99), emphasis was placed on those aspects considered to be serious obstacles to mining at ultra-depth, e.g. the effect of barometric pressure changes on health, the risk of mining-induced 
seismicity, and the cost of refrigeration and ventilation. During the second year, a new focus on the transport of personnel, material and rock was introduced. During the third year, the emphasis was placed on the integration of the research findings and the formulation of guidelines for the designers and operators of future ultra-deep mines. During the final two years, emphasis was placed on the transfer of knowledge and technology through activities such as schools, consultancy reviews on mines operated by the industrial partners, and the commercialisation of services and technologies. More than 200 researchers contributed to the programme. Notable outputs of DeepMine include the development and commercialisation of borehole radar systems to detect geological structures ahead of mining, computer packages to simulate mine cooling and ventilation, and integrated assessments of mine layouts that took rock engineering factors, cooling and logistics into account.

FutureMine (2002-2004) was the successor to DeepMine (Durrheim 2007). In an environment characterised by a volatile gold price, depleting orebodies and aging infrastructure, the gold mining companies recognised that the major challenges facing the industry were the reduction of working costs (from USD 250/oz to USD 170/oz or lower at the time) and the improvement of health and safety. This would not only result in an increase in profit, but the reduced pay limit would convert lower grade resources into mineable reserves, thereby increasing total output and extending the life of the mines. FutureMine complemented and extended DeepMine in the following respects:

1. DeepMine addressed future ultra-deep operations, while FutureMine addressed current underground gold mining operations. Consequently, DeepMine tended to be knowledge-driven, while FutureMine was technology-driven with a strong emphasis on the implementation of solutions within a three year horizon. FutureMine research teams worked closely with manufacturers and technology suppliers.

2. DeepMine worked on the assumption that a new part of an orebody would be developed, providing the opportunity to install new technologies and systems from scratch. In contrast, FutureMine generally worked within the constraints of existing infrastructure, where the costs and benefits of modernising or replacing technologies and systems had to be evaluated. Research work commenced in August 2001. The budget for the three year programme was about ZAR $50 \mathrm{~m}$.

\section{1 st century research, development and implementation initiatives}

\subsection{Social, economic and political climate}

The first democratic elections were held in South Africa in 1994 and heralded changes in the social, political and economic climate in South Africa that have had a major impact on the mining sector, including research and development activities. South African mining companies were now free to operate globally and sought to reduce their exposure to deep mining and its enormous capital requirements, and embarked on overseas exploration programmes, acquisitions and mergers. In-house research laboratories were downsized, as was the Chamber of Mines Research Organisation. The advent of democracy was accompanied by a rise in trade union influence and activism, resulting in an improvement in real wages and working conditions. In January 2014 more than 70,000 platinum miners went on a five month strike for higher wages. 
Legislation such as the Mineral and Petroleum Resources Development Act was promulgated to regularise the mineral rights ownership issues and consolidate all older mining laws. A side issue is the enablement of previously disadvantaged South African citizens to participate in the mining sector as owners and managers, not just labourers (Act No. 28 of 2002. Its amendment, Act 49 of 2008, has not been promulgated). The basis of the South African economy was, and continues to be scrutinised, with some civil society organisations and political parties advocating the nationalisation of mines. The ruling party, the African National Congress (ANC), commissioned an in-depth study of how to maximise the impact of the nation's mineral endowment on development. A discussion document, entitled "State Intervention in the Minerals Sector" was released in 2012 (ANC 2012). It concluded that maximum impact will not be produced by market forces alone. The key area of state intervention was seen to be in the "development of quality technical human resources (engineers, scientists and technicians) at which we are currently failing badly" (ANC 2012).

The government also appointed a National Planning Commission in 2010 to identify the future growth path of South Africa and the challenges that the country will face in the next 20 years. The key aim is to "eliminate poverty and reduce inequality by 2030 through uniting South Africans, unleashing the energies of its citizens, growing an inclusive economy, building capabilities, enhancing the capability of the state and leaders working together to solve complex problems" (National Planning Commission 2012). The National Development Plan was published in 2012 (National Planning Commission 2012). It reaffirmed mining as one of the cornerstones of the economy "providing jobs and a vital source of foreign exchange" (National Planning Commission 2012). The National Planning Commission recommends support for focused research and development to enable improved extraction methods that lengthen mine life, with better energy efficiency and less water intensity.

Since 2003 there has been a drastic decline in the deep mining research effort in South Africa. Support for the collaborative research programmes waned. MHSC funding through SIMRAC has remained largely static and the emphasis has shifted from safety to health issues. At the same time, public awareness of the environmental legacy of gold mining has also increased as old mines have been allowed to flood and acidic waters have reached the surface and required treatment at considerable expense to the taxpayer. The rising groundwater also triggered earthquakes that shook Johannesburg (Mchunu 2013).

\subsection{A systems view of rock engineering research applied to deep mining}

SIMRAC commissioned a holistic assessment of rock-related research in South Africa by an international review panel (Durrheim 2005). As part of the review, technologies that had emerged during the last two decades were identified and summarised in a table that categorises technology according to the risk management strategy, the time to implement, the impact on other systems, and the technology-readiness level. This table has been updated to reflect the current situation (Table 1). 


\section{Table 1 Technologies for managing the rockburst risk in South African mines}

\begin{tabular}{|c|c|c|c|}
\hline \multirow{2}{*}{$\begin{array}{c}\text { RISK } \\
\text { MANAGEMENT } \\
\text { STRATEGY }\end{array}$} & \multicolumn{3}{|c|}{$\begin{array}{l}\text { NATURE OF TECHNOLOGY/TIME TO IMPLEMENT/IMPACT } \\
\text { ON OTHER MINING SYSTEMS } \\
\text { ates technology-readiness level: Mature, implementation widespread; } \\
\text { en in certain environments, some research and development required; } \\
\text { pt or prototype, considerable research and development required. }\end{array}$} \\
\hline & $\begin{array}{l}\text { STRATEGIC } \\
\text { Years to months, } \\
\text { major impact }\end{array}$ & $\begin{array}{l}\text { TACTICAL } \\
\text { Months to weeks, } \\
\text { moderate impact }\end{array}$ & $\begin{array}{l}\text { OPERATIONAL } \\
\text { Weeks to days, } \\
\text { minor impact }\end{array}$ \\
\hline $\begin{array}{l}\text { Identifying } \\
\text { hazardous } \\
\text { structures and } \\
\text { stress regimes }\end{array}$ & $\begin{array}{l}\text { 3D reflection seismics } \\
\text { Mine-wide seismic } \\
\text { networks }\end{array}$ & $\begin{array}{l}\text { Local seismic networks } \\
\text { Borehole radar } \\
\text { Seismic hazard assessment } \\
\text { High stress measurements } \\
\text { Integration of numerical } \\
\text { modelling and seismics }\end{array}$ & $\begin{array}{l}\text { Rapid deployment } \\
\text { seismic monitors } \\
\text { Techniques to predict } \\
\text { seismicity }\end{array}$ \\
\hline $\begin{array}{l}\text { Reducing strain } \\
\text { accumulation } \\
\text { through regional } \\
\text { support }\end{array}$ & $\begin{array}{l}\text { Dip pillar layouts } \\
\text { Backfill } \\
\text { Large diameter } \\
\text { drill-and-fill } \\
\text { Probabilistic mine design }\end{array}$ & & \\
\hline $\begin{array}{l}\text { Protecting the } \\
\text { worker through } \\
\text { better support } \\
\text { systems or by } \\
\text { stress-relieving } \\
\text { the rock }\end{array}$ & & $\begin{array}{l}\text { Yielding pre-stressed } \\
\text { props and headboards } \\
\text { Yielding tunnel support } \\
\text { Roofbolts and nets } \\
\text { Thin spray-on liners }\end{array}$ & Preconditioning \\
\hline $\begin{array}{l}\text { Removing the } \\
\text { worker from the } \\
\text { hazardous area } \\
\text { through } \\
\text { mechanisation }\end{array}$ & $\begin{array}{l}\text { Large diameter } \\
\text { drill-and-fill } \\
\text { Long hole drilling } \\
\text { Impact mining system } \\
\text { Activated rock cutting } \\
\text { Mini-disk rock cutting } \\
\text { Electric rock breaking }\end{array}$ & $\begin{array}{l}\text { Remote controlled LHDs } \\
\text { and dozers } \\
\text { 'Walking' face area support }\end{array}$ & $\begin{array}{l}\text { Drill rigs and jigs } \\
\text { Remote controlled } \\
\text { drills }\end{array}$ \\
\hline
\end{tabular}

It is gratifying that some significant progress has been achieved during the past decade. For example, technologies such as borehole radar, seismic hazard assessment techniques, backfill, roofbolts and nets have been moved from the 'field-proven in certain environments' category to the 'mature, implementation widespread' category; technologies to measure high stresses and to integrate numerical modelling and seismics have been moved from the 'concept or prototype' category to the 'field-proven in certain environments' category. A new entry is the drill-and-fill technology being field-tested by Anglogold Ashanti.

The assessment recommended that SIMRAC continue to support a holistic and proactive programme of research to mitigate the rockfall and rockburst risk and build capacity. Firstly, the research programme should cover the entire innovation cycle, including basic science, engineering, risk assessment, human factors and technology transfer. Secondly, it should address emerging rock-related hazards associated with coal pillar and multi-seam mining, small scale mining, and deep platinum mining. Thirdly, it should also seek 
to play a role in the development of highly skilled rock engineering practitioners and researchers. Following this assessment, a new project was scoped, entitled 'Minimizing the rockburst risk'. As part of the conceptualisation process, a rockburst cause-and-effect chain was developed allowing multiple opportunities for intervention to be identified (Table 2). This project was terminated prematurely as SIMRAC could not reach consensus on the scope of work.

\subsection{CSIR research into real time risk management tools and novel mining methods}

Over the last decade CSIR has conducted research aimed at reducing risk in stopes where current drill-and-blast mining methods are employed, as well as the development of novel mining methods. In the standard South African underground hard rock mining cycle, blastholes are drilled into the face of a 30 m long panel and loaded with explosives. The mine is then evacuated and the explosives are detonated. Over the next few hours fumes and dust are vented, while the stope cools (the broken rock introduces considerable heat into the stope) and seismicity subsides. The cleaning shift then removes the broken ore using scrapers or water jets that are operated from safe positions in gullies. The first task of the day-shift miners is to inspect the recently blasted stope and make it safe before the crew enters to install support and drill blastholes. A pinch bar is used to sound the hanging wall. Any loose rock is barred down or supported.

CSIR is developing technology to map the fragility of the hanging wall prior to the entry of the stope crew. The system consists of four main components:

1. A microphone and signal analyser to assist the person using the pinch bar assess the integrity of the hanging wall.

2. A thermal camera and image analyser to identify slabs that are slightly cooler than the surrounding rock, indicating that the slab is separated from the hanging wall by a crack.

3. A navigation device that records the position of each sounding and thermal image.

4. A device that scans the stope and produces a 3D image of the stope, including the support elements.

The ultimate goal is to develop a suite of instruments that can be mounted on an autonomous robotic platform so that the task of pre-entry inspection can be carried out by a machine rather than a human. The electronic sounding device, thermal imager, and positioning system are described by Brink (2010), and the robotic platform by Teleka et al. (2011). CSIR is still in the stage of developing technology demonstrators, which are tested in a simulated stope and easily accessible underground sites (Figure 2). 


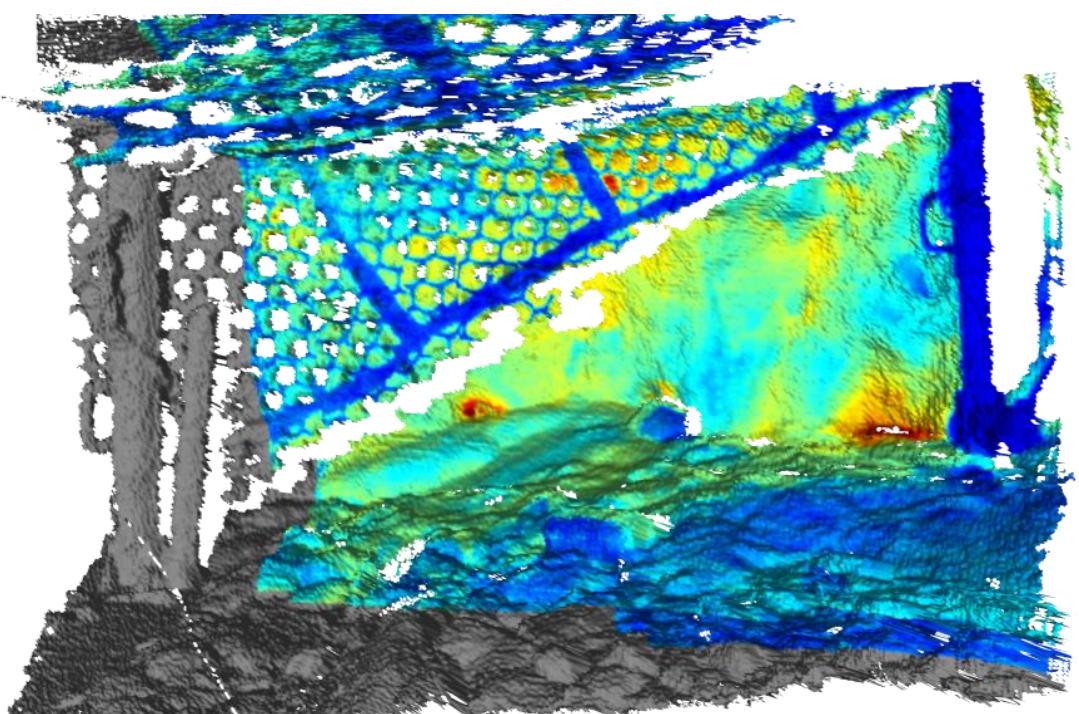

Figure 2 Laser scan of $\sim 1 \mathrm{~m}$ high simulated stope with temperature image draped on the topography (Price et al. 2011)

Table 2 Rockburst cause-and-effect chain

\begin{tabular}{|c|c|c|c|c|}
\hline CAUSE & $\begin{array}{l}\text { EFFECT } \\
\text { Benign/ } \\
\text { Positive } \\
\text { Possibly } \\
\text { negative }\end{array}$ & Why? & $\begin{array}{l}\text { Potential } \\
\text { engineering } \\
\text { solutions to } \\
\text { achieve the } \\
\text { benign or positive } \\
\text { effect }\end{array}$ & $\begin{array}{l}\text { Examples of R\&D that is } \\
\text { needed to develop the } \\
\text { engineering solution }\end{array}$ \\
\hline Mining & $\begin{array}{l}\text { Small volumes } \\
\text { of rock } \\
\text { removed } \\
\text { Large volumes } \\
\text { of rock } \\
\text { removed }\end{array}$ & $\begin{array}{l}\text { Only the } \\
\text { precious metal } \\
\text { is mined } \\
\text { Both the } \\
\text { precious metal } \\
\text { and the rock is } \\
\text { mined }\end{array}$ & $\begin{array}{l}\text { Radically new } \\
\text { mining methods }\end{array}$ & $\begin{array}{l}\text { In situ leaching } \\
\text { Machines to mine the (thin) } \\
\text { reef }\end{array}$ \\
\hline $\begin{array}{l}\text { Large } \\
\text { volumes of } \\
\text { rock removed }\end{array}$ & $\begin{array}{l}\text { Small/no } \\
\text { volume of } \\
\text { rock close to } \\
\text { failure } \\
\text { Large volume } \\
\text { of rock } \\
\text { stressed close } \\
\text { to failure }\end{array}$ & $\begin{array}{l}\text { Limited or } \\
\text { elastic } \\
\text { deformation }\end{array}$ & $\begin{array}{l}\text { Limit the } \\
\text { deformation, e.g. } \\
\text { - Small spans } \\
\text { - Backfill } \\
\text { Limit the excess } \\
\text { shear stress }\end{array}$ & $\begin{array}{l}\text { Better mining layouts, e.g. } \\
\text { - Bord and pillar, } \\
\text { - Closely spaced dip pillars } \\
\text { - Bracket/buttress pillars } \\
\text { Better backfilling } \\
\text { Map rock mass ( } 200-2,000 \mathrm{~m} \\
\text { range) to detect large } \\
\text { faults/dykes }\end{array}$ \\
\hline $\begin{array}{l}\text { Large volume } \\
\text { of rock } \\
\text { stressed close }\end{array}$ & $\begin{array}{l}\text { Plastic } \\
\text { deformation }\end{array}$ & $\begin{array}{l}\text { Strain energy } \\
\text { gradually } \\
\text { released }\end{array}$ & $\begin{array}{l}\text { Control the } \\
\text { redistribution of } \\
\text { stress in the rock }\end{array}$ & $\begin{array}{l}\text { Better mining methods, e.g. } \\
\text { - De-stressing/ } \\
\text { preconditioning }\end{array}$ \\
\hline
\end{tabular}




\begin{tabular}{|c|c|c|c|c|}
\hline to failure & Violent failure & $\begin{array}{l}\text { Strain energy } \\
\text { instantaneously } \\
\text { released }\end{array}$ & mass & $\begin{array}{l}\text { - Mining rates and sequences } \\
\text { Better use of seismology, e.g. } \\
\text { - Seismic/modelling } \\
\text { integration } \\
\text { - Medium term (1-100 day) } \\
\text { hazard assessment methods }\end{array}$ \\
\hline $\begin{array}{l}\text { Violent } \\
\text { failure }\end{array}$ & $\begin{array}{l}\text { Weak ground } \\
\text { motion in } \\
\text { working areas } \\
\text { Strong ground } \\
\text { motion in } \\
\text { working areas }\end{array}$ & $\begin{array}{l}\text { Energy release } \\
\text { remote from } \\
\text { working areas } \\
\text { Energy release } \\
\text { close to working } \\
\text { areas }\end{array}$ & $\begin{array}{l}\text { Separate the } \\
\text { seismic source } \\
\text { and working } \\
\text { place, e.g. } \\
\text { - }>30^{\circ} \\
\text { face/structure } \\
\text { - Mining } \\
\text { towards solid } \\
\text { and/or away } \\
\text { from structures } \\
\text { - Bracket pillars }\end{array}$ & $\begin{array}{l}\text { Assessment/refinement of rock } \\
\text { engineering principles and } \\
\text { layouts } \\
\text { Map rock mass ( } 10-200 \mathrm{~m} \\
\text { range) to detect faults/dykes } \\
\text { and estimate rock mass rating }\end{array}$ \\
\hline CAUSE & $\begin{array}{l}\text { EFFECT } \\
\text { Benign/ } \\
\text { Positive } \\
\text { Possibly } \\
\text { negative }\end{array}$ & Why? & $\begin{array}{l}\text { Potential } \\
\text { engineering } \\
\text { solutions to } \\
\text { achieve the } \\
\text { benign or positive } \\
\text { effect }\end{array}$ & $\begin{array}{l}\text { Examples of R\&D that is } \\
\text { needed to develop the } \\
\text { engineering solution }\end{array}$ \\
\hline $\begin{array}{l}\text { Strong } \\
\text { ground } \\
\text { motion in } \\
\text { working } \\
\text { areas }\end{array}$ & $\begin{array}{l}\text { No ejection } \\
\text { and/or fall of } \\
\text { ground } \\
\text { Ejection } \\
\text { and/or fall of } \\
\text { ground }\end{array}$ & $\begin{array}{l}\text { Roof and face } \\
\text { stable and/or } \\
\text { adequately } \\
\text { supported } \\
\text { Roof and face } \\
\text { unstable and/or } \\
\text { inadequately } \\
\text { supported }\end{array}$ & $\begin{array}{l}\text { Improve hanging } \\
\text { wall control, e.g. } \\
\text { smoothness } \\
\text { Improve } \\
\text { effectiveness of } \\
\text { local support }\end{array}$ & $\begin{array}{l}\text { Blasting techniques } \\
\text { Ergonomics/cost of support } \\
\text { Hanging wall-support } \\
\text { interaction } \\
\text { Map the rock mass ( } 1-10 \mathrm{~m} \\
\text { range) to detect partings and } \\
\text { fractures }\end{array}$ \\
\hline $\begin{array}{l}\text { Ejection } \\
\text { and/or fall of } \\
\text { ground }\end{array}$ & $\begin{array}{l}\text { No/little risk } \\
\text { of injury } \\
\text { Moderate/ } \\
\text { high } \\
\text { probability of } \\
\text { injury }\end{array}$ & $\begin{array}{l}\text { Exposure is low } \\
\text { Exposure is high }\end{array}$ & $\begin{array}{l}\text { Mechanisation of } \\
\text { in-stope } \\
\text { operations (e.g. } \\
\text { drilling, cleaning) } \\
\text { Ensure events } \\
\text { occur when } \\
\text { working places } \\
\text { are evacuated } \\
\text { (e.g. at blasting } \\
\text { time) } \\
\text { Alerts }\end{array}$ & $\begin{array}{l}\text { Mechanisation } \\
\text { Local support } \\
\text { elements/systems } \\
\text { Short term (<1 day) hazard } \\
\text { assessment methods }\end{array}$ \\
\hline
\end{tabular}




\begin{tabular}{|c|c|c|c|c|}
\hline \multirow[t]{2}{*}{$\begin{array}{l}\text { Moderate/ } \\
\text { high } \\
\text { probability of } \\
\text { injury }\end{array}$} & $\begin{array}{l}\text { Risk of injury } \\
\text { mitigated }\end{array}$ & $\begin{array}{l}\text { Protection from } \\
\text { falling/ejected } \\
\text { rock } \\
\text { Workers hide or } \\
\text { flee }\end{array}$ & $\begin{array}{l}\text { Alarms } \\
\text { Protective } \\
\text { equipment } \\
\text { Remote control } \\
\text { equipment }\end{array}$ & \multirow[t]{2}{*}{$\begin{array}{l}\text { Aftershock studies } \\
\text { Alarms (e.g. activity rate) } \\
\text { Temporary supports and } \\
\text { shields } \\
\text { Size distribution of FOGs/ejecta }\end{array}$} \\
\hline & $\begin{array}{l}\text { Severe } \\
\text { injuries/ } \\
\text { death }\end{array}$ & & & \\
\hline \multirow[t]{2}{*}{$\begin{array}{l}\text { Severe } \\
\text { injuries } \\
\text { and/or } \\
\text { deaths }\end{array}$} & Inquiry only & $\begin{array}{l}\text { Requirements of } \\
\text { the Mine Health } \\
\text { \& Safety Act, } \\
2002 \text { are } \\
\text { satisfied }\end{array}$ & $\begin{array}{l}\text { Competent } \\
\text { mining and rock } \\
\text { engineering } \\
\text { practice }\end{array}$ & $\begin{array}{l}\text { Implementation of knowledge } \\
\text { and technology produced by } \\
\text { research }\end{array}$ \\
\hline & $\begin{array}{l}\text { Inquiry, } \\
\text { prosecution } \\
\text { and } \\
\text { punishment }\end{array}$ & $\begin{array}{l}\text { Shortcomings in } \\
\text { compliance and } \\
\text { practice }\end{array}$ & & \\
\hline
\end{tabular}

In addition, a sonic closure meter and strong ground motion seismograph are being developed to monitor the rock mass continuously. The goal is to develop low-cost, low-power wireless instruments that can survive in the hot, humid and dusty in-stope environment.

In the last two decades, CSIR has investigated a range of alternatives to drill-and-blast such as impact rippers, which take advantage of the stress-induced fractures in the face; activated disk cutters, that superimposed a vibration on the rock cutting tool; mini disk cutters, that take advantage of the greater point stresses generated by small diameter cutting disks; and various types of electrical discharges such as the plasma hole-maker, which uses high voltage sparks to break the rock.

\subsection{Chamber of Mines Learning Hub}

The Chamber of Mines established the Learning Hub in 2009 to encourage mining companies to learn from the pockets of excellence that exist in the industry through an adoption process which involves identifying, documenting, demonstrating and facilitating widespread adoption of leading practices with the greatest potential to address the major risks in health and safety areas such as falls of ground, transport and machinery, dust and noise (MOSH 2014). The Learning Hub is currently developing three leading practices to reduce the risk posed by falls of ground.

1. The Triggered Action Response Plan (TARP) leading practice, which consists of a set of documented and known hazards that must be continuously checked for, and a pre-classified risk classification. The responsible person has to react according to this plan, triggering a process that escalates the problem to the level of responsibility that is required to deal with it.

2. The Entry Examination and Making Safe leading practice, which involves the entire crew in examination of their working place and in taking measures to prevent falls of ground.

3. The Nets with Bolts leading practice, which integrates hanging wall nets with a roofbolt support system.

\subsection{Observational studies in South African mines to mitigate seismic risks}

A five year Japan-South Africa collaborative project ( USD $3 \mathrm{~m}$ ) entitled 'Observational studies in South African mines to mitigate seismic risks' was launched in August 2010 under the auspices of the JST-JICA Science and Technology Research Partnership for Sustainable Development (SATREPS) (Ogasawara et al. 2009; Durrheim et al. 2010). The project draws on over a century of studies of mining-related and tectonic 
earthquakes by South African and Japanese researchers, respectively (Durrheim 2010; Utsu 2003). The project has four main aims:

1. To learn more about earthquake preparation and triggering mechanisms by deploying arrays of sensitive sensors within rock volumes where mining is likely to induce seismic activity.

2. To learn more about earthquake rupture and rockburst damage phenomena by deploying robust strong ground motion sensors close to potential fault planes and within mining excavations.

3. To upgrade the South African surface national seismic network in the mining districts.

4. To develop human capacity and research infrastructure in South Africa (Durrheim et al. 2012).

To our knowledge it is the most ambitious observational mine-seismology research project ever undertaken in terms of the number of sites and sensors and the scope of research. The project is only briefly described here, as it is the subject of another paper in this volume (Ogasawara et al. 2014).

Research sites were established at three deep gold mines in the Witwatersrand Basin of South Africa:

1. Cooke \#4 Shaft (previously Ezulwini).

2. Hlanganani Shaft of the Kloof-Driefontein Complex (KDC).

3. Moab Khotsong (Durrheim et al. 2012). 
Boreholes were drilled to locate faults that were considered capable of producing future mining-induced seismicity accurately. Acoustic emission sensors, strain- and tilt meters, and controlled seismic sources were installed to monitor the quasi-static deformation of the rock mass, the accumulation of strain and damage during the earthquake preparation phase, and changes in dynamic stress produced by the propagation of the rupture front during a seismic event. Stopes close to the target faults were instrumented. Rock types, joints, faults, veins and stress-induced fractures were recorded in the diamond borehole cores, as well as the types and performance of the installed support units.

Reliable evaluations of seismic hazard depend on a reasonably accurate description of the initial stress conditions, either as an input to numerical modelling of the stress field, or as in situ stress information. However, stress measurements are rarely carried out in South African mines. One of the main reasons is that the drilling diameter required for overcoring is much larger than the diameters used on mines for regular geological drilling. The drilling of large diameter holes is slower and more expensive, and a single overcoring measurement often takes several days to perform. The compact conical-ended borehole overcoring ( $\mathrm{CCBO}$ ) technique determines the 3D stress tensor by a single overcoring of a strain cell consisting of 16 or 24 strain gauges (Sugawara \& Obara 1999). Ogasawara et al. (2012) reduced the overcoring and associated tools to BX size while keeping the aspect ratio unchanged so that the published strain coefficients could be used. This modified method was tested at depths greater than $3 \mathrm{~km}$ on three different mines. It was demonstrated that three overcoring measurements can be made within two shifts (Ogasawara et al. 2013).

Masao Nakatani of the Earthquake Research Institute at Tokyo University and his team installed a network of 28 acoustic emission (AE) sensors at a depth of about $1 \mathrm{~km}$ at Cooke \#4 mine (Naoi et al. 2012; Moriya et al. 2012). The network was sufficiently sensitive to locate events with $M_{w}$ as small as -5 (Figure 3). Data acquired by the network has already been analysed to investigate several fundamental questions relevant to the feasibility of earthquake prediction (Durrheim \& Ogasawara 2012). For example:

1. Over what magnitude range do earthquake phenomena scale? This is useful in determining the applicability of laboratory investigations $\left(10^{-2}\right.$ to $1 \mathrm{~m}$ scale) that often exhibit precursors to failure, to mining-induced earthquakes ( 1 to $10^{3} \mathrm{~m}$ scale) and tectonic earthquakes ( $10^{3}$ to $10^{6} \mathrm{~m}$ scale).

2. Is there any temporal or spatial change in seismicity prior to a large event, e.g. acceleration in the rate of seismicity, a change in the frequency-magnitude distribution or a clustering in space that indicates nucleation?

All these parameters have been suggested as possible precursors to large seismic events. If measureable changes are found to occur reliably, they could be used to provide a warning of an impending event. 


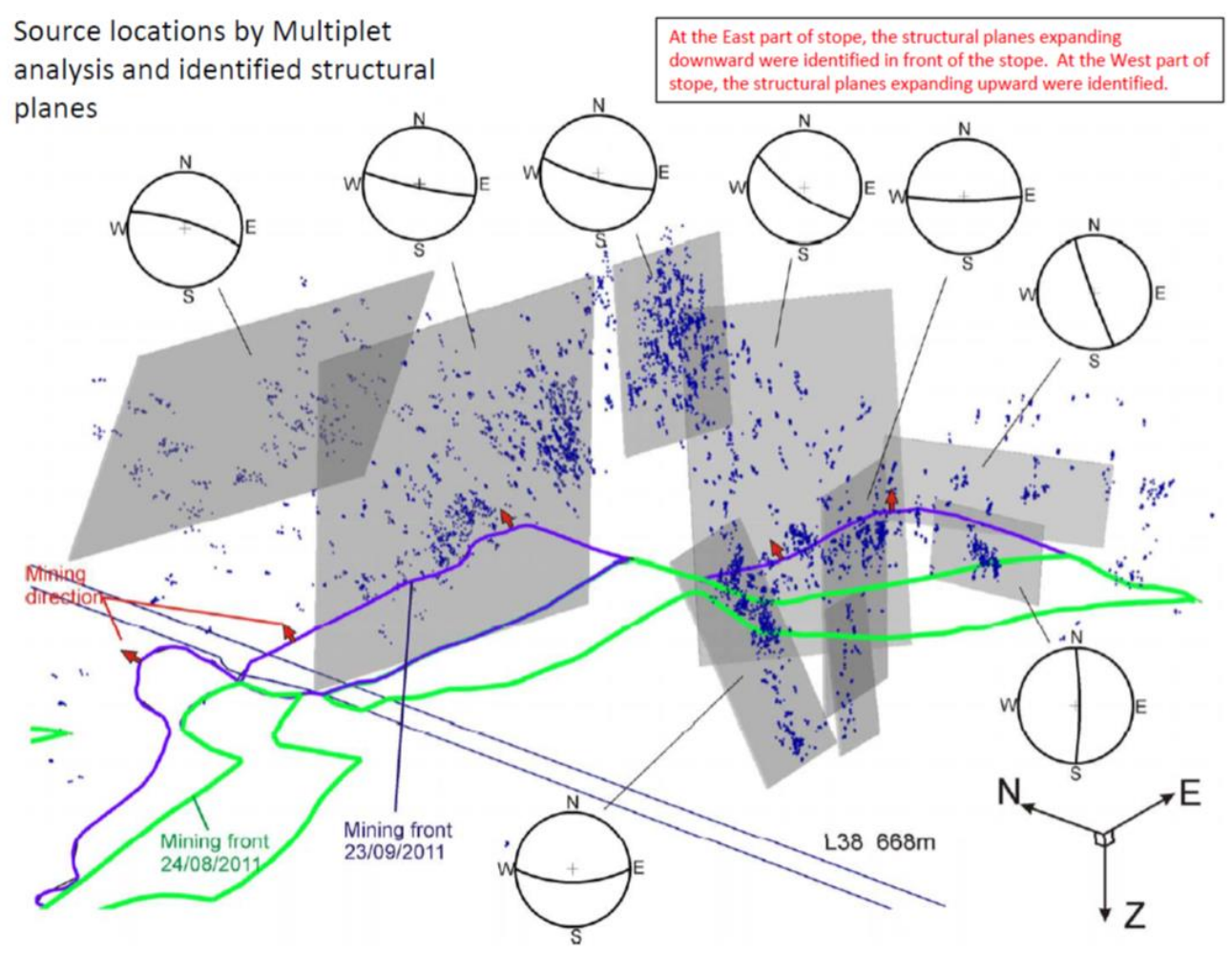

Figure 3 AE events in Cook \#4 shaft pillar located by multiplet analysis defining eight
structural planes (after Moriya et al. 2012)

\subsection{Anglogold Ashanti Technology Innovation Consortium (2012-present)}

Numerous rock-breaking technologies have been tested in the past two decades under the auspices of COMRO, CSIR and various collaborative research programmes. These range from incremental improvements to the conventional drill-and-blast method (e.g. rigs, jigs and remote controls) and long hole drilling, to fully-mechanised narrow reef mining systems (impact rippers, activated and mini-disc cutters) and low-energy explosives and propellants. While some technical successes were achieved, none of these methods have been implemented on a large scale to date.

In 2012, Anglogold Ashanti established a technology innovation consortium that is seeking to implement alternative and unconventional mining technologies that will reduce the exposure of workers to hazardous environments in deep mines. A technology that is currently being tested in the shaft pillar at TauTona Mine simply involves the use of a raise bore to drill out the reef using locally developed equipment, and then filling the hole with very stiff and strong backfill. It was reported that this method has already produced $40 \mathrm{~kg}$ of gold, albeit in an area that has exceptionally high grades (Creamer 2014a).

\subsection{D reflection seismics}

Technology that was developed to search for oil and gas reservoirs has been adapted to search for metal and mineral deposits in the hard rock environment (Malehmir et al. 2012). Reflection seismic methods were first implemented in the Witwatersrand Basin in the 1980s, rejuvenating exploration activities and contributing to the discovery of the South Deep orebody (Haslett 1994) and new resources in the Bothaville Gap (Gray et al. 1994; Tucker et al. 1994). South Deep mine has since come into production. With some $78 \mathrm{~m} \mathrm{oz}$ of resources and $29 \mathrm{~m} \mathrm{oz}$ of reserves, it is one of the world's premier gold orebodies. A comprehensive review of the use of reflection seismology to map the Witwatersrand Basin is provided by Pretorius et al. (2003). The seismic reflection method was introduced into the Bushveld Complex following the success of the method in the Witwatersrand Basin, and has proved useful both for exploration and for mine planning in the Bushveld Complex. A comprehensive review has been published by Campbell (2011). 
The Witwatersrand Basin and the Paleoproterozoic Transvaal Basin that overlies it have a lengthy tectonic history. Four basin-forming events occurred between 2.7 and $2 \mathrm{Ga}$, resulting in the deposition of the volcanic-sedimentary sequences of the Klipriviersberg Group, and the sedimentary Platberg, Chuniespoort and Pretoria Groups (Dankert \& Hein 2010). Several 3D reflection seismic surveys that cover the West Rand and Far West Rand goldfields and were acquired between 1988 and 2003 were recently merged, reprocessed using modern techniques (such as attribute analysis) and reinterpreted by Manzi et al. (2012b, Figure 4), yielding new insights into the tectonic evolution of the basin (Manzi et al. 2013). The reprocessed data has also been used to map structures that might have an influence on safety, such as faults and dykes, particularly those that might carry high-pressure water or flammable gases (Manzi et al. 2012a, 2014).

\section{$5 \quad$ Conclusions}

Gold was discovered near present-day Johannesburg in 1886 and platinum in the northeastern part of the country in 1924. As the mines deepened, rockbursts and rising rock temperatures posed a risk to mine workers. The State appointed various committees to investigate health and safety in the industry, the first in 1908, followed by others in 1915, 1924, 1964, 1994 and 2005. Research was conducted on an ad hoc basis until 1964, when the Chamber of Mines of South Africa established its own research organisation (COMRO). Research organisations and practitioners devised new mine layouts, improved support elements and systems, and developed real time digital seismic networks to monitor the response of the rock mass to mining. Mining at depth would have been impossible without these advances, and a significant reduction in fatalities and injuries has been achieved.

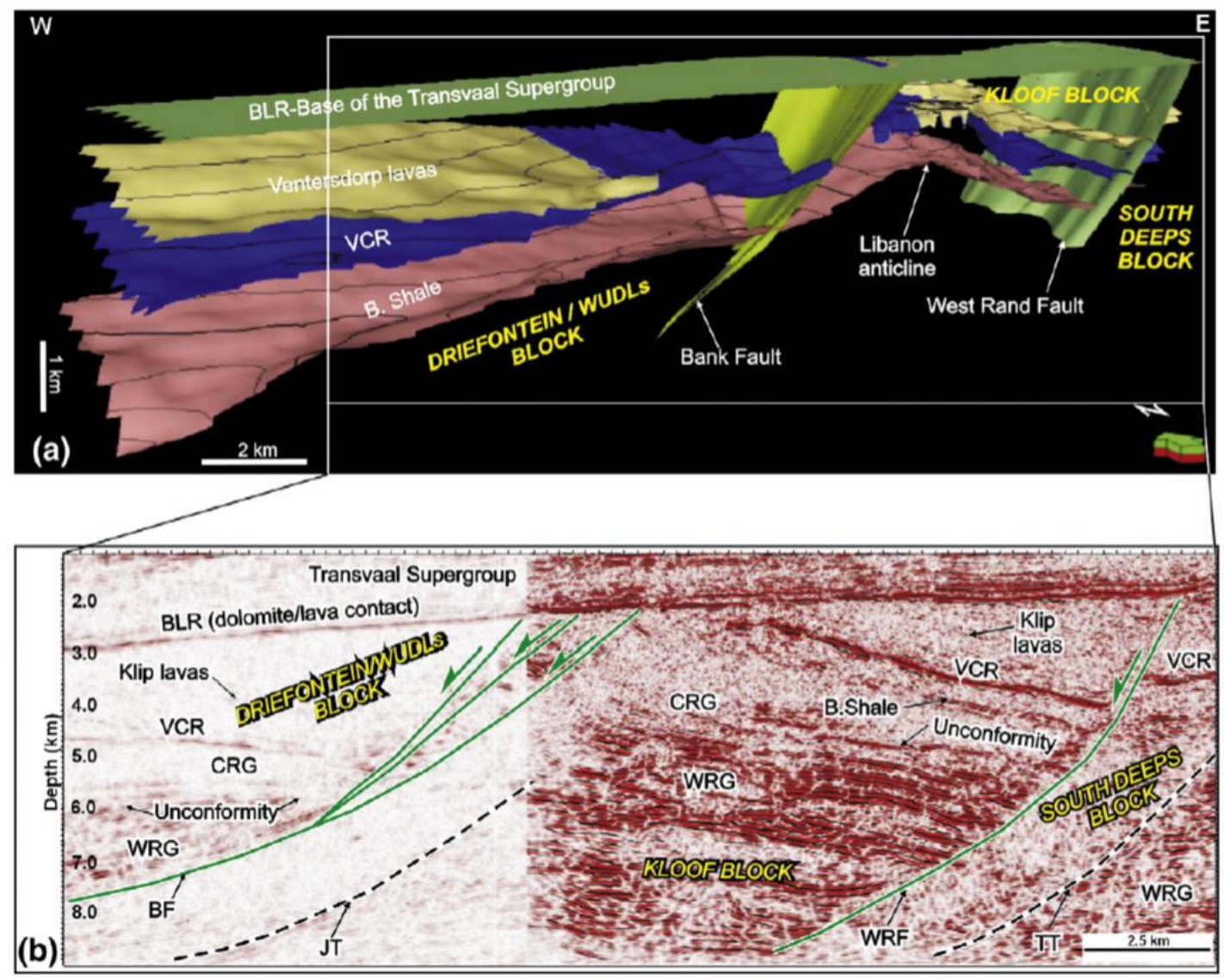

Figure 4 Seismic model across the Far West Rand goldfields (Manzi et al. 2013); (a) 3D regional seismic model showing the geometry of West Rand Fault, Bank Fault and Libanon Anticline; (b) regional crossline seismic section through Western Ultra Deep Levels (WUDLs), Driefontein, Kloof and South Deep mines showing the West Rand Fault (WRF), Bank Fault (BF), Tandeka Thrust (TT) and Jabulani Thrust (JT). BLR - Black Reef, VCR - Ventersdorp Contact Reef, B Shale - 


\section{Booysens Shale, WRG - West Rand Group, CRG - Central Rand Group, Klip - Klipriviersberg Group}

South Africa's gold production peaked at 1,000 metric $\mathrm{t}$ in 1970. Inevitably, orebodies have been depleted and production had declined to $167 \mathrm{t}$ by 2012; levels that are comparable with the output in 1905 . State and industry support for research has also fallen, so it is not surprising that the research and development capacity has declined drastically. COMRO closed in 1993, as have the CSIR laboratories for the testing of rock properties, support elements, and backfill. The CSIR Centre for Mining Innovation was disaggregated in 2014, although CSIR still will seek to service the mining sector through other units. One positive result is that many ex-COMRO/CSIR researchers have joined the ranks of practitioners and collaborators, aiding the transfer of knowledge. Nevertheless, gold and platinum mining continues to make a significant contribution to the South African economy through wages, tax and foreign exchange earnings. While the accident rate has improved significantly, especially over the last two decades, there is still room for improvement as fatality and injury rates remain higher than international safety benchmarks. An obvious means of reducing the risk further is to reduce the exposure of workers to hazardous conditions in the face area.

This keynote paper poses a question: has R\&D contributed to improvements in safety and profitability of deep South African mines? Taking the long view, there is no doubt that deep mining would have been impossible without innovation, much of it local. Why then, has there been such a decline in research funding, capacity and activity? In my view, the answer to this simple question is rather complicated. Firstly, depletion of ore reserves led to a decline in production and reluctance to invest in long-term research. Secondly, following the advent of democracy in 1994, government funding was focused on urgent issues such as poverty, unemployment and crime that needed immediate redressing. Mining was regarded as a mature and wealthy industry. Mining companies were able to operate globally, and pursued easier opportunities elsewhere. Nevertheless, mining companies will continue to undertake and sponsor research, but, as noted by Professor Huw Phillips (retired Head, School of Mining Engineering, University of the Witwatersrand) in an editorial in the April 2014 issue of the Journal of the South African Institute of Mining and Metallurgy:

"This confidential research is often piecemeal, with contracts awarded worldwide to institutions and individuals who are experts in particular areas. The result has been a dearth of opportunities for young people in South Africa to develop their skills in mining research under the mentorship of experienced researchers" (Phillips 2014).

Nevertheless, local research efforts continue. An ambitious five year Japan-South Africa research programme 'Observational studies in South African mines to mitigate seismic risks' was initiated in 2010, and Anglogold Ashanti is currently testing a drill-and-fill method to mine gold ore. A rise in labour activism and a demand for higher wages will most likely accelerate the drive for mechanisation.

It is hoped that the South African experience will be useful as the global mining sector seeks to provide resources for future generations. Many of these deposits are likely to mined at depth or found in lessexplored parts of the world, such as Africa and the Tethyan Belt (Lambert et al. 2013). The developing world is likely to insist on an equitable share of the benefits of mining and has a growing sensitivity to the environmental and social costs. While technical advances are critically important, it is clear that the sustainability of deep mining is inextricably linked to the social, political and economic landscape. Innovation needs to meet these demands as well.

\section{Acknowledgement}

The ideas and findings reported in this keynote paper are the fruits of three decades involvement in R\&D in the mining sector. Many people have served as mentors and collaborators, notably Rod Green, Branko Corner, Güner Gürtunca, Steve Spottiswoode, Mike Roberts, John Napier, Art McGarr, Dave Ortlepp, Dave Diering, Denis Labrie and Hiroshi Ogasawara. Support from the Council for Scientific and Industrial Research, the Department of Science and Technology of South Africa through the South African Research 
Chairs Initiative, University of the Witwatersrand, and the JST-JICA Science and Technology Research Partnership for Sustainable Development is gratefully acknowledged.

\section{References}

Adams, DJ \& Van der Heever, PK 2001, 'An overview of seismic research co-ordinated by SIMRAC since its inception', in G van Aswegen, RJ Durrheim \& WD Ortlepp (eds), Proceedings of the Fifth International Symposium on Rockbursts and Seismicity in Mines, The South African Institute of Mining and Metallurgy, Johannesburg, pp. 205-212.

ANC 2012, State Intervention in the Minerals Sector, viewed 7 July 2014, http://www.anc.org.za/docs/discus/2012/sims.pdf Anon. 1916, Report of the Witwatersrand Rock Burst Committee 1915, The Government Printing and Stationery Office, Pretoria.

Anon. 1925, Report of the Witwatersrand Earth Tremors Committee 1924, The Government Printer, Cape Town.

Anon. 1964, Recommendations of the Rock Burst Committee 1964, Department of Mines, Cape Town.

Brink, AVZ 2010, 'Real time risk assessment of hangingwall/roof stability in deep South African mines', in M Van Sint Jan \& Y Potvin (eds), Proceedings of the Fifth International Symposium on Deep and High Stress Mining, Australian Centre for Geomechanics, Perth, pp. 477-490.

Campbell, G 2011, 'Exploration geophysics of the Bushveld Complex in South Africa', The Leading Edge, vol. 30, pp. 622-637.

Creamer, M 2013, 'Economist calls on South Africa to save pivotal gold-mining industry', Mining Weekly, 3 October 2013, viewed 28 May 2014, http://www.miningweekly.com/article/economist-calls-on-south-africa-to-save-pivotal-gold-mining-industry2013-10-03

Creamer, M 2014a, 'Exciting new gold mechanisation achieving more success - Anglogold', Mining Weekly, 19 February 2014, viewed 28 May 2014, http://www.miningweekly.com/article/exciting-new-gold-mechanisation-achieving-more-successanglogold-2014-02-19.

Creamer, M 2014b, 'Govt lauded for AMD paradigm shift, but complexity not fully grasped', Mining Weekly, 18 April 2014, viewed 28 May 2014, http://www.miningweekly.com/article/govt-lauded-for-amd-paradigm-shift-but-detractors-insist-it-hasntfully-grasped-complexity-of-the-issue-2014-04-18-1.

Dankert, BT \& Hein, KAA 2010, 'Evaluating the structural character and tectonic history of the Witwatersrand Basin', Precambrian Research, doi: 10.1016/j.precamres.2009.10.007, vol. 177, pp. 1-22.

Department of Mineral Resources 2012, Report by the Chief Inspector of Mines, Mr D. Msiza, to the Parliamentary Portfolio Committee, viewed 28 May 2014, http://www.parliament.gov.za/live/contentpopup.php?Item_ID=2041\&Category_ID=

Durrheim, RJ 2005, 'Towards best practice in rock-related research: a holistic assessment of the SIMRAC programme', Proceedings of the Third Southern African Rock Engineering Symposium: Best practices in rock engineering, South African Institute of Mining and Metallurgy, Johannesburg, pp. 1-12.

Durrheim, RJ 2007, 'The DeepMine and FutureMine Research Programmes - Knowledge and Technology for Deep Gold Mining in South Africa', in Y Potvin, J Hadjigeorgiou \& TR Stacey (eds), Challenges in Deep and High Stress Mining, Australian Centre for Geomechanics, Perth, pp. 131-141.

Durrheim, RJ 2010, 'Mitigating the risk of rockbursts in the deep hard rock mines of South Africa: 100 years of research', in J Brune (ed), Extracting the Science: a Century of Mining Research, Society for Mining, Metallurgy, and Exploration, Inc., Englewood, pp. 156-171.

Durrheim, RJ \& Ogasawara, H 2012, 'Can mine tremors be predicted? Observational studies of earthquake nucleation, triggering and rupture in South African mines', Proceedings of the Second Southern Hemisphere International Rock Mechanics Symposium, South African Institute of Mining and Metallurgy, Johannesburg, pp. 327-343.

Durrheim, RJ, Brown, ET, Kaiser, PK \& Wagner, H 2005, A holistic assessment of SIMRAC rock-related research to date, Final Report, project SIM 04-02-06, Mine Health and Safety Council, Johannesburg.

Durrheim, RJ, Anderson, RL, Cichowicz, A, Ebrahim-Trollope, R, Hubert, G, Kijko, A, McGarr, A, Ortlepp, WD \& Van der Merwe, N 2006, Investigation into the risks to miners, mines, and the public associated with large seismic events in gold mining districts, Department of Minerals and Energy, Pretoria.

Durrheim, RJ, Ogasawara, H, Nakatani, M, Yabe, Y, Milev, A, Cichowicz, A, Kawakata, H, Moriya, H \& the JST-JICA SA Research Group 2010, 'Observational Study to Mitigate Seismic Risks in Mines: a new Japanese - South African collaborative project', in M Van Sint Jan \& Y Potvin (eds), Proceedings of the Fifth International Symposium on Rockbursts and Seismicity in Mines, Australian Centre for Geomechanics, Perth, pp. 215-225.

Durrheim, RJ, Ogasawara, H, Nakatani, M, Yabe, Y, Kawakata, H, Naoi, M, Ward, AK, Murphy, SK, Wienand, J, Lenegan, P, Milev, AM, Murakami, O, Yoshimitsu, N, Kgarume, T, Cichowicz, A \& the SATREPS research group 2012, 'Establishment of SATREPS experimental sites in South African gold mines to monitor phenomena associated with earthquake nucleation and rupture', in Y Potvin (ed.), Proceedings of the Sixth International Seminar on Deep and High Stress Mining, Australian Centre for Geomechanics, Perth, pp. 173-187.

Gray, NK, Tucker, RE \& Kershaw, DJ 1994, 'The Sun Project-I. Discovery of a major new Witwatersrand goldfield', in CR Anhaeusser (ed.), Proceedings of the XVth Council of Mining and Metallurgical Institutions Congress, vol. 3, South African Institute of Mining and Metallurgy, Johannesburg, pp. 95-102.

Handley, JRF 2004, Historic Overview of the Witwatersrand Goldfields, Handley, Howick.

Haslett, MJ 1994, 'The South Deep Project: Geology and planning for the future', in CR Anhaeusser (ed.), Proceedings of the XVth Council of Mining and Metallurgical Institutions Congress, vol. 3, South African Institute of Mining and Metallurgy, pp. 71-83. 
Lambert, I, Durrheim, R, Godoy, M, Kota, M, Leahy, P, Ludden, J, Nickless, E, Oberhaensli, R, Anjian, W \& Williams, N 2013, 'Resourcing Future Generations: a proposed new IUGS initiative', Episodes, vol. 36, no. 2, pp. 82-86.

Mchunu, S 2013, 'Acid mine drainage has Jo'burg quaking', Mail \& Guardian, 5 December 2013, viewed 28 May 2014, http://mg.co.za/article/2013-12-05-acid-mine-drainage-has-joburg-quaking.

Malehmir, A, Durrheim, R, Bellefleur, G, Urosevic, M, Juhlin, C, White, D, Milkereit, B \& Campbell, G 2012, 'Seismic methods in mineral exploration and mine planning: A general overview of past and present case histories and a look into the future', Geophysics, vol. 77, pp. WC173-WC190.

Manzi, M, Durrheim, RJ, Hein, KAA \& King, N 2012a, '3D edge detection seismic attributes used to map potential conduits for water and methane in deep gold mines in the Witwatersrand basin, South Africa', Geophysics, vol. 77, pp. WC133-WC147.

Manzi, MSD, Gibson, MAS, Hein, KAA, King, N \& Durrheim, RJ 2012b, 'Application of 3D seismic techniques in evaluation of ore resources in the West Wits Line goldfield and portions of the West Rand Goldfield, South Africa', Geophysics, vol. 77, pp. WC163-WC171.

Manzi, MSD, Hein, KAA, King, N \& Durrheim, RJ 2013, Neoarchaean tectonic history of the Witwatersrand Basin and Ventersdorp Supergroup: New constraints from high-resolution 3D seismic reflection data, Tectonophysics, vol. 590, pp. 94-105.

Manzi, MSD, Hein, KAA, Durrheim, RJ \& King, N 2014, 'Integration of 3D seismic, in-mine geological mapping and exploration borehole data to model the orebody at Kloof gold mine, South Africa', International Journal of Rock Mechanics \& Mining Sciences, vol. 66, pp. 97-113.

Moriya, H, Naoi, M, Nakatani, M, Murakami, O, Kgarume, T, Ward, AK, Durrheim, R, Philipp, J, Yabe, Y, Kawakata, H \& Ogasawara, H 2012, 'Detection of mining-induced fractures around a stope in Ezulwini gold mine, South Africa, by using AE events with similar waveforms', Proceedings of the 21st International Acoustic Emission Symposium, Japanese Society for Non-Destructive Inspection, Okinawa Prefecture Municipal Center, Naha, pp. 181-186.

MOSH 2014, The Chamber of Mines Learning Hub, MOSH, viewed 7 July 2014, http://www.mosh.co.za/

Naoi, M, Nakatani, M, Philipp, J, Horiuchi, S, Otsuki, K, Kgarume, T, Morema, G, Khambule, S, Masakale, T, Miyakawa, K, Watanabe, A, Moriya, H, Murakami, O, Yabe, Y, Kawakata, H, Yoshimitsu, N \& Ogasawara, H 2012, 'AE measurements at 1 km depth in a deep South African gold mine and their activities related to two M0 earthquakes', Abstracts, Japanese Geosciences Union Meeting 2012, SSS28-07.

National Planning Commission 2012, National Development Plan 2030, National Planning Commission, viewed 7 July 2014 , http://www.gov.za/issues/national-development-plan/development-plan-2012.html.

Ogasawara, H, Durrheim, RJ, Nakatani, M, Yabe, Y, Milev, A, Cichowicz, A, Kawakata, H \& Moriya, H 2009, 'JST-JICA SA research group, a Japanese - South African collaboration to mitigate seismic risks in deep gold mines', in J Van der Westhuizen (ed.), Proceedings of the First Hard Rock Safe Safety Conference, South African Institute of Mining and Metallurgy, Johannesburg, pp. 115-134.

Ogasawara, H, Kato, H, Hofmann, G \& De Bruin, P 2012, 'Trial of the BX conical-ended borehole overcoring stress measurement technique', Journal of the South African Institute of Mining and Metallurgy, vol. 102, pp. 749-754.

Ogasawara, H, Hofmann, G, Kato, H, Nakatani, M, Moriya, H, Naoi, M, Yabe, Y, Durrheim, R, Cichowicz, A, Kgarume, T, Milev, A, Murakami, O, Satoh, T \& Kawakata, H 2013, 'In-situ monitoring and modelling of the rock mass response to mining: Japanese-South African collaborative research', in A Malovichko \& D Malovichko (eds), Proceedings of the Eighth International Symposium on Rockbursts and Seismicity in Mines, Geophysical Survey of Russian Academy of Sciences, Moscow, pp. 51-60.

Ogasawara, H, Nakatani, M, Durrheim, RJ, Naoi, M, Yabe, Y, Moriya, H, Hofmann, GF, Stander, C, Roberts, DP, de Bruin, P, Oelofse, J, Kato, H, Cichowicz, A, Birch, D, Ngobeni, D, Milev, A, Kgarume, T, Satoh, T, Horiuchi, S, Kawakata, H, Murakami, O, Yoshimitsu, N, Ward, AK, Wienand, J, Lenegan, P, Yilmaz, H, Mngadi, S, Piper, PS, Clements, TN, Nakao, S, Okubo, M, Ishii, H \& Visser, AV 2014, 'Observational studies of the rock mass response to mining in highly stressed gold mines in South Africa', in M Hudyma and Y Potvin (eds), Proceedings of the Seventh International Conference on Deep and High Stress Mining, Australian Centre for Geomechanics, Perth, pp. 123-138.

Pretorius, CC, Muller, MR, Larroque, M \& Wilkens, C 2003, 'A review of 16 years of hardrock seismics on the Kaapvaal Craton', in DW Eaton, B Milkereit \& MH Salisbury (eds), Hardrock Seismic Exploration, Geophysical Developments Series No. 10, Society of Exploration Geophysicists, Tulsa, pp. 247-268.

Price, M, Green, J \& Dickens, J 2011, 'Creating Thermal Maps of Mines', Proceedings of the Fourth Robotics and Mechatronics Conference of South Africa, Council for Scientific and Industrial Research, Pretoria, p. 23.

Sugawara, K \& Obara, Y 1999, 'Draft ISRM suggested method for in situ stress measurement using the compact conical-ended borehole overcoring (CСBO) technique', International Journal of Rock Mechanics and Mining Sciences, vol. 36, pp. 307-322.

Tucker, RE, Schlegel, GC-J, Wagener, JHE \& Gray, NK 1994, 'The Sun Project-II. Scientific and technological innovations in a Witwatersrand exploration venture', in CR Anhaeusser (ed.), Proceedings of the XVth Council of Mining and Metallurgical Institutions Congress, vol. 3, South African Institute of Mining and Metallurgy, Johannesburg, pp. 103-116.

Teleka, SR, Green JJ \& Brink, S 2011, 'The automation of the "making safe" process in South African hard-rock underground mines', in MK Khan \& NL Win (eds), Proceedings of the 26th International Conference on CAD/CAM, Robotics and Factories of the Future, vol. 2, International Society for Productivity Enhancement, pp. 532-540.

Tucker, RE, Schlegel, GC-J, Wagener, JHE \& Gray, NK 1994, 'The Sun Project-II. Scientific and technological innovations in a Witwatersrand exploration venture', in CR Anhaeusser (ed.), Proceedings of the XVth Council of Mining and Metallurgical Institutions Congress, vol. 3, South African Institute of Mining and Metallurgy, Johannesburg, pp. 103-116. 
Utsu, T 2003, 'Centennial Report of Japan Part 2, Historical development of Seismology in Japan', in W Lee, P Jennings, C Kisslinger \& H Kanamori (eds), International Handbook of Earthquake \& Engineering Seismology, Part B, Academic Press, London, pp. 1377-1391.

Viljoen, MJ \& Reimold, WU 1999, An Introduction to South Africa's Geological and Mining Heritage, The Geological Society of South Africa and Mintek, Randburg. 